\title{
Cohnella fontinalis sp. nov., a xylanolytic bacterium isolated from fresh water
}

Correspondence

Hatsumi Shiratori

siratori@brs.nihon-u.ac.jp

\author{
Hatsumi Shiratori, Yudai Tagami, Teruhiko Beppu and Kenji Ueda
}

Life Science Research Center, College of Bioresource Sciences, Nihon University, 1866 Kameino, Fujisawa 252-0880, Japan

\begin{abstract}
A novel xylan-degrading bacterium, $\mathrm{YT}-1101^{\top}$, was isolated from fresh water. The isolate was a Gram-reaction-negative, aerobic, motile, endospore-forming and rod-shaped bacterium.

Phylogenetic analysis of the $16 \mathrm{~S}$ rRNA gene sequence indicated that strain $\mathrm{YT}-1101^{\top}$ belonged to the genus Cohnella, sharing sequence similarities of less than $94 \%$ with the type species. The genomic $\mathrm{G}+\mathrm{C}$ content was 58.6 mol\%. The predominant menaquinone was MK-7. The major fatty acids were anteiso- $C_{15: 0}$, iso- $C_{16: 0}$ and iso- $C_{15: 0}$. Major polar lipids were diphosphatidylglycerol, phosphatidylglycerol and phosphatidylethanolamine. On the basis of morphological, physiological and phylogenetic properties, strain $\mathrm{YT}-1101^{\top}$ represents a novel species of the genus Cohnella, for which the name Cohnella fontinalis sp. nov. is proposed. The type strain is $\mathrm{YT}^{-1101^{\top}}\left(=\mathrm{NBRC} 104957^{\top}=\mathrm{DSM} 21753^{\top}\right)$.
\end{abstract}

The genus Cohnella was proposed by Kämpfer et al. (2006) as a homogeneous group within the family Paenibacillaceae. The members of the genus are aerobic, spore-forming and contain MK-7 as the main menaquinone and some kinds of phosphatidylglycerol as the predominant polar lipid. The genus is also characterized by the presence of two unknown phospholipids and four unknown aminophospholipids. García-Fraile et al. (2008) emended the description of the genus Cohnella as follows: cells are non-motile or motile, and most species are thermotolerant; predominant polar lipids are diphosphatidylglycerol, phosphatidylglycerol and phosphatidylethanolamine. At the time of writing, the genus Cohnella consisted of four species with validly published names (http://www.bacterio.cict.fr/c/cohnella.html): Cohnella thermotolerans (type strain isolated from industrial starch production), Cohnella hongkongensis (human blood), Cohnella laeviribosi (a volcanic area) and Cohnella phaseoli (a root nodule of Phaseolus coccineus).

Recently, we isolated bacteria that required a high- $\mathrm{CO}_{2}$ atmosphere and studied their 16S rRNA gene sequences (Ueda et al., 2008). The results highlighted the potential diversity of such bacteria and showed that the use of high$\mathrm{CO}_{2}$ air helps in effective mining of uncultured microorganisms. In this study, we characterized one of the isolates taxonomically, strain $\mathrm{YT}-1101^{\mathrm{T}}$, which belonged to the genus Cohnella. This is the first report of the isolation of a member of this group of bacteria from the hydrosphere.

The GenBank/EMBL/DDBJ accession number for the 16S rRNA gene of strain $\mathrm{YT}-1101^{\top}$ is $\mathrm{AB} 362828$.

Micrographs of strain YT-1 $101^{\top}$ and results of 2D TLC of its polar lipids are available as supplementary material with the online version of this paper.
In the original isolation process, YT- $1101^{\mathrm{T}}$ was one of the strains that exhibited marked dependence on a high- $\mathrm{CO}_{2}$ atmosphere; however, after successive cultivation, the isolate became culturable even under a normal atmosphere, as did several other isolates (Ueda et al., 2008). Here, to characterize its physiological properties, strain YT-1101 was grown aerobically under a normal atmosphere for 12 days at $40{ }^{\circ} \mathrm{C}$ on tryptic soy agar (TSA; Difco) adjusted to $\mathrm{pH}$ 7.0. The bacterium was maintained as a glycerol suspension $(20 \%, \mathrm{w} / \mathrm{v})$ or by using Microbank (Pro-Lab Diagnostics) at $-80{ }^{\circ} \mathrm{C}$. The reference strains $C$. thermotolerans DSM $17683^{\mathrm{T}}$, C. hongkongensis DSM $17642^{\mathrm{T}}, C$. phaseoli DSM $19269^{\mathrm{T}}$ and C. laeviribosi CCUG $52217^{\mathrm{T}}$ were obtained from the DSMZ or CCUG.

Cell morphology was observed under a BZ-9000 phasefluorescence microscope (Keyence), a VE-8800 scanning electron microscope (Keyence) and a JEM-1200EX electron microscope (JEOL), using cells grown for $24 \mathrm{~h}$ at $40{ }^{\circ} \mathrm{C}$. For transmission electron microscopy, cells were fixed with $2.0 \%$ $(\mathrm{v} / \mathrm{v})$ glutaraldehyde and $2.0 \%(\mathrm{v} / \mathrm{v})$ osmium tetroxide. Samples were embedded in Epoxy resin (Epon 812). Ultrathin sections were prepared using an LKB-8800 ultramicrotome. Specimens were stained with uranyl acetate solution (containing $2.0 \%$ uranyl acetate and lead citrate) and exposed to carbon vapour prior to observation. Motility was investigated in wet mounts under a Zeiss Axioskop 2 optical microscope (Carl Zeiss Microimaging) at 12 and $48 \mathrm{~h}$. Flagella were stained by the method of Toda (1928). The Gram reaction was performed following the method described by Bartholomew \& Mittwer (1952). Oxidase was tested using oxidase reagent (bioMérieux) according to the instructions of the manufacturer. Catalase activity was determined by treating cells with $3.0 \%(\mathrm{w} / \mathrm{v}) \mathrm{H}_{2} \mathrm{O}_{2}$ and observing formation 
of bubbles. To test biochemical characteristics, the methods of Tindall et al. (2007) were used for the following tests: hydrolysis of agar $(1.0 \%, \mathrm{w} / \mathrm{v})$, casein $(5.0 \%, \mathrm{w} / \mathrm{v})$, starch $(1.0 \%$, $\mathrm{w} / \mathrm{v})$, DNA $(0.2 \%, \mathrm{w} / \mathrm{v})$, chitin $(2.0 \%, \mathrm{w} / \mathrm{v})$, tyrosine $(0.5 \%$, $\mathrm{w} / \mathrm{v})$, xylan $(1.0 \%, \mathrm{w} / \mathrm{v})$ and powdered cellulose (type D; Advantec) $(1.0 \%, \mathrm{w} / \mathrm{v})$; nitrate reduction; indole production; gelatin liquefaction; and activities of urease, lecithinase (using egg yolk agar) and lipase (using Tweens 20, 40 and 80 at $1.0 \%$, $\mathrm{w} / \mathrm{v}$ ). Carbon source utilization tests and additional physiological tests were performed by using API $50 \mathrm{CH}$ (with API CHB/E medium), API 20E and API 20NE galleries according to the instructions of the manufacturer (bioMérieux). The range of temperature $\left(20,28,30,35,37,40,45,50\right.$ and $\left.60{ }^{\circ} \mathrm{C}\right)$ and salinity $[0,0.2,0.4,0.6,0.8,1,2,4,8,10,15$ and $20 \% \mathrm{NaCl}$ $(\mathrm{w} / \mathrm{v})]$ for growth were determined after $24 \mathrm{~h}$ cultivation in tryptic soy broth (TSB; Difco). The $\mathrm{pH}$ range for growth was assessed in TSB at $0.5 \mathrm{pH}$ unit intervals between $\mathrm{pH} 5.0$ and 12.0 using $100 \mathrm{mM}$ citrate phosphate buffer ( $\mathrm{pH}$ 5.0-5.5), $100 \mathrm{mM}$ sodium phosphate buffer ( $\mathrm{pH} 6.0-8.5), 100 \mathrm{mM}$ sodium carbonate buffer ( $\mathrm{pH} 9.0-10.0)$ and $100 \mathrm{mM}$ sodium sesquicarbonate $/ \mathrm{NaOH}$ buffer $(\mathrm{pH} 10.5-12.0)$. Growth was judged by the increase of optical density or decrease of $\mathrm{pH}$ after $24 \mathrm{~h}$ of cultivation. Growth on nutrient agar (Difco), R2A (Difco) and MacConkey agar (Oxoid) was also studied at $40{ }^{\circ} \mathrm{C}$. Growth under anaerobic conditions was checked using an Anoxomat Mark II system (Mart Microbiology) after 10 days incubation at $40{ }^{\circ} \mathrm{C}$ on TSA.

Cells of YT- $1101^{\mathrm{T}}$ were aerobic, spore-forming, motile rods. The cells were peritrichously flagellated (Supplementary Fig. S1a, b, available in IJSEM Online). Although the Gramstaining reaction was negative, the cell-wall ultrastructure resembled that of Gram-positive bacteria (Supplementary Fig. S1c, d). Central or subterminal ellipsoidal endospores were observed in swollen sporangia. Observation using transmission electron microscopy revealed that the surface of the spores was covered with spikes, and that the spores exhibited a star-shape morphology in cross-section (Supplementary Fig. S1e, f). Colonies on TSA were translucent, cream-coloured, low-convex and circular with irregular edges, $1.0-1.5 \mathrm{~mm}$ in diameter. Strain YT- $1101^{\mathrm{T}}$ grew on nutrient agar and R2A, but not on MacConkey agar. Strain YT- $1101^{\mathrm{T}}$ and all members of Cohnella except $C$. hongkongensis showed xylanolytic activity (Table 1). Other physiological and biochemical characteristics of YT- $1101^{\mathrm{T}}$ are summarized in Table 1 and the species description.

Chemotaxonomic characterization of $\mathrm{YT}-1101^{\mathrm{T}}$ was carried out using cells cultured in TSB for $24 \mathrm{~h}$ at $40{ }^{\circ} \mathrm{C}$. DNA was extracted by using a bacterial genomic DNA purification kit (Edge Biosystems). The DNA G $+\mathrm{C}$ content of YT$1101^{\mathrm{T}}$, determined by an HPLC method (Mesbah \& Whitman, 1989), was $58.6 \mathrm{~mol} \%$ (mean of three measurements). The fatty acid methyl esters of YT- $1101^{\mathrm{T}}$ were extracted and analysed according to the standard protocol of the Sherlock Microbial Identification System (version 5.0; MIDI). As shown in Table 2, the major fatty acids of YT- $1101^{\mathrm{T}}$ were anteiso- $\mathrm{C}_{15: 0}$, iso- $\mathrm{C}_{16: 0}$ and iso- $\mathrm{C}_{15: 0}$, which accounted for $68.1 \%$ of the total fatty acids in
Table 1. Differential characteristics of strain $\mathrm{YT}-1101^{\top}$ and type strains of Cohnella species

Strains: 1, Cohnella fontinalis sp. nov. $\mathrm{YT}_{1101^{\mathrm{T}}} ; 2$, C. thermotolerans CCUG $47242^{\mathrm{T}}$ (data from Kämpfer et al., 2006; Cho et al., 2007); 3, C.

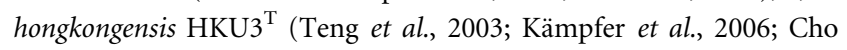
et al., 2007); 4, C. laeviribosi RI-39 ${ }^{\mathrm{T}}$ (Cho et al., 2007); 5, C. phaseoli $\mathrm{GSPCl}^{\mathrm{T}}$ (García-Fraile et al., 2008). Data for reference strains were based on the previous studies indicated except that xylanase activity of all species and colony colour of $C$. thermotolerans were observed in this study using the strains mentioned in the text. +, Positive; -, negative; w, weakly positive; ND, no data available.

\begin{tabular}{|lccccc|}
\hline Characteristic & $\mathbf{1}$ & $\mathbf{2}$ & $\mathbf{3}$ & $\mathbf{4}$ & $\mathbf{5}$ \\
\hline Colony colour & $\mathrm{C}$ & $\mathrm{WH}$ & $\mathrm{G}$ & $\mathrm{WH}$ & $\mathrm{WH}-\mathrm{C}$ \\
Motility & + & - & - & - & + \\
Temperature range $\left({ }^{\circ} \mathrm{C}\right)$ & $25-55$ & $20-55$ & $37-65$ & $30-60$ & $10-45$ \\
Growth at pH 8.5 & + & $\mathrm{ND}$ & $\mathrm{ND}$ & - & - \\
Growth in 2\% NaCl & + & $\mathrm{ND}$ & $\mathrm{ND}$ & - & + \\
Gram-staining reaction & - & + & - & + & + \\
Catalase/oxidase & $+/+$ & $\mathrm{ND} /+$ & $\mathrm{w} /+$ & $+/-$ & $+/ \mathrm{W}$ \\
Nitrate reduction & + & $\mathrm{ND}$ & + & $\mathrm{ND}$ & - \\
Xylanase & + & + & - & + & + \\
Assimilation of carbon sources & & & & & \\
$\quad$ Mannitol & + & - & - & + & - \\
$\quad N-$ Acetyl-D-glucosamine & - & - & + & - & + \\
$\quad$ Gluconate & + & + & + & - & - \\
DNA G+C content & 58.6 & 59 & 60.9 & 51 & 60.3 \\
$\quad(m o l \%)$ & & & & & \\
\hline
\end{tabular}

${ }^{*} \mathrm{C}$, Cream; G, grey; wH, white.

TSB; this feature is common to members of the genus Cohnella. However, the fatty acid profile of YT- $1101^{\mathrm{T}}$ differed from those of the other Cohnella species in terms of the absence of unsaturated fatty acids and the greater proportion of iso- $C_{17: 0}$. The major respiratory quinone was determined to be MK-7 (99.6\%); in addition, a small amount of MK-8 was detected $(0.4 \%)$ by an HPLC method (Nishijima et al., 1997). This quinone profile supports the affiliation of YT- $1101^{\mathrm{T}}$ to the genus Cohnella (Kämpfer et al., 2006).

Polar lipid extraction and identification were performed according to Komagata \& Suzuki (1987). Sugar- and choline-containing lipids were detected by using $p$ anisaldehyde and Dragendorff reagent, respectively. The spots were identified by using a phospholipid kit (Funakoshi) as a standard and referring to previous descriptions regarding polar lipid profiles of Cohnella species (Kämpfer et al., 2006; Cho et al., 2007; García-Fraile et al., 2008). The dried lipid fraction was dissolved in chloroform/methanol $(2: 1, \mathrm{v} / \mathrm{v})$ and subjected to HPTLC (Merck silica gel 60, 10 $\times 10 \mathrm{~cm}$ ). Solvent systems used for two-dimensional development were chloroform/methanol/ water $(65: 25: 4$ by vol.) in the first dimension and chloroform/acetic acid/methanol/water $(80: 15: 12: 4$ by 
Table 2. Cellular fatty acid compositions of strain $\mathrm{YT}-1101^{\top}$ and type strains of the genus Cohnella

Strains: 1, C. fontinalis sp. nov. YT- $1101^{\mathrm{T}} ; 2$, C. thermotolerans CCUG $47242^{\mathrm{T}}$; 3, C. hongkongensis $\mathrm{HKU}^{\mathrm{T}}$; 4, C. laeviribosi RI-39 ${ }^{\mathrm{T}}$; 5, C. phaseoli $\mathrm{GSPC1}^{\mathrm{T}}$. The three major fatty acids for each taxon are shown in bold. Data for reference type strains are from Cho et al. (2007) and García-Fraile et al. (2008). Values are percentages of total fatty acids. tr, Trace $(<1 \%)$; ND, not detected. $\mathrm{C}_{13: 0}$ and $\mathrm{C}_{18: 0}$ were not detected in any strain.

\begin{tabular}{|c|c|c|c|c|c|}
\hline Fatty acid & 1 & 2 & 3 & 4 & 5 \\
\hline \multicolumn{6}{|l|}{ Saturated } \\
\hline $\mathrm{C}_{14: 0}$ & 1.0 & 1.0 & 5.0 & 1.9 & 1.8 \\
\hline $\mathrm{C}_{15: 0}$ & 2.3 & 1.4 & 8.0 & 1.3 & 5.3 \\
\hline $\mathrm{C}_{16: 0}$ & 12.5 & 6.6 & 25.3 & 9.2 & 8.9 \\
\hline $\mathrm{C}_{17: 0}$ & $\operatorname{tr}$ & ND & 1.2 & $\operatorname{tr}$ & $\operatorname{tr}$ \\
\hline \multicolumn{6}{|l|}{ Unsaturated } \\
\hline $\mathrm{C}_{14: 1} \omega 5 c$ & $\mathrm{ND}$ & $\mathrm{ND}$ & $\mathrm{ND}$ & $\operatorname{tr}$ & ND \\
\hline $\mathrm{C}_{16: 1} \omega 7 c$ & ND & ND & $\mathrm{ND}$ & ND & 1.9 \\
\hline $\mathrm{C}_{16: 1} \omega 11 c$ & $\mathrm{ND}$ & ND & $\operatorname{tr}$ & $\operatorname{tr}$ & 1.2 \\
\hline $\mathrm{C}_{17: 1} \omega 6 c$ & $\mathrm{ND}$ & 1.0 & $\mathrm{ND}$ & $\operatorname{tr}$ & ND \\
\hline iso- $\mathrm{C}_{17: 1}$ & $\mathrm{ND}$ & 1.1 & 1.9 & ND & $\mathrm{ND}$ \\
\hline $\mathrm{C}_{18: 1} \omega 7 c$ & $\mathrm{ND}$ & 4.0 & $\mathrm{ND}$ & ND & ND \\
\hline \multicolumn{6}{|l|}{ Branched } \\
\hline iso- $\mathrm{C}_{12: 0}$ & $\mathrm{ND}$ & $\mathrm{ND}$ & $\mathrm{ND}$ & ND & $\operatorname{tr}$ \\
\hline iso- $\mathrm{C}_{13: 0}$ & $\operatorname{tr}$ & $\mathrm{ND}$ & $\operatorname{tr}$ & $\operatorname{tr}$ & $\operatorname{tr}$ \\
\hline anteiso- $\mathrm{C}_{13: 0}$ & $\mathrm{ND}$ & ND & $\mathrm{ND}$ & $\operatorname{tr}$ & 1.4 \\
\hline iso- $\mathrm{C}_{14: 0}$ & 4.0 & 2.1 & 2.3 & 3.9 & 2.6 \\
\hline iso- $\mathrm{C}_{15: 0}$ & 14.3 & 3.2 & 8.1 & 11.7 & 14.3 \\
\hline anteiso- $\mathrm{C}_{15: 0}$ & 33.2 & 28.4 & 31.2 & 22.0 & 44.5 \\
\hline iso- $\mathrm{C}_{16: 0}$ & 20.6 & 45.5 & 11.9 & 40.5 & 14.1 \\
\hline iso- $\mathrm{C}_{17: 0}$ & 7.2 & ND & ND & 2.8 & 3.1 \\
\hline anteiso- $\mathrm{C}_{17: 0}$ & 4.3 & 6.7 & 2.6 & 5.8 & 2.3 \\
\hline
\end{tabular}

vol.) in the second dimension. Spots were visualized using $50 \%$ aqueous sulfuric acid.

Strain YT- $1101^{\mathrm{T}}$ contained diphosphatidylglycerol, phosphatidylglycerol and phosphatidylethanolamine as the predominant polar lipids (Supplementary Fig. S2). This was consistent with the polar lipids profiles of Cohnella species (Kämpfer et al., 2006; Cho et al., 2007; García-Fraile et al., 2008). An unknown phospholipid (PL2) and two unknown aminophospholipids (PN1 and PN2) were also detected. Lysyl phosphatidylglycerol and glycolipid were not detected. No spots were observed with Dragendorff reagent. The polar lipid pattern of YT- $1101^{\mathrm{T}}$ was distinct from those of $C$. thermotolerans, $C$. hongkongensis and $C$. laeviribosi in the absence of lysyl phosphatidylglycerol and that of $C$. phaseoli in the absence of glycolipids. In addition, the absence of unknown phospholipids and aminophospholipids with low $R_{\mathrm{f}}$ values (PL3, PL4, PN3 and PN4) distinguished $\mathrm{YT}-1101^{\mathrm{T}}$ from the other Cohnella species that contain either type of phospholipid.

The 16S rRNA gene of YT- $1101^{\mathrm{T}}$ was obtained by PCR amplification using a bacterial domain-specific primer set, 27F/1492R (Wang et al., 2007). PCR was performed on a
T1 Thermocycler (Biometra) using Ex Taq polymerase (Takara-shuzo). The PCR protocol included an initial denaturation period of $4 \mathrm{~min}$ at $94{ }^{\circ} \mathrm{C}, 30$ cycles of $94{ }^{\circ} \mathrm{C}$ for $1 \mathrm{~min}, 55^{\circ} \mathrm{C}$ for $1 \mathrm{~min}$ and $72{ }^{\circ} \mathrm{C}$ for $1 \mathrm{~min}$, a final elongation step at $72{ }^{\circ} \mathrm{C}$ for $3 \mathrm{~min}$ and incubation at $4{ }^{\circ} \mathrm{C}$ until further processing. The nucleotide sequence of the 16S rRNA gene fragment was determined directly by using the BigDye terminator version 3.1 cycle sequencing kit on an ABI 3130 Genetic Analyzer (Applied Biosystems). Phylogenetic analyses were performed using CLUSTAL W (Thompson et al., 1994) and MEGA 3.1 (Kumar et al., 2004). Phylogenetic trees were constructed by neighbour-joining (Saitou \& Nei, 1987) and maximum-parsimony (Fitch, 1971) methods. The evolutionary distance matrix for the neighbour-joining method was generated according to Kimura's two-parameter model (Kimura, 1983). To evaluate the topology of the resultant tree, bootstrap analysis (Felsenstein, 1985) with 1000 resamplings was used. The $16 \mathrm{~S}$ rRNA gene sequence of YT $-1101^{\mathrm{T}}(1518 \mathrm{bp})$ was compared with those from the GenBank/EMBL/DDBJ nucleotide sequence database, using the BLAST program (http://www.ncbi.nlm.nih.gov/BLAST/).

The 16S rRNA gene sequence identity of YT- $1101^{\mathrm{T}}$ to the type strains of $C$. thermotolerans, $C$. hongkongensis, $C$. laeviribosi and C. phaseoli was 92.6, 93.8, 93.2 and 93.4\%, respectively. These identity scores were low enough, according to Stackebrandt \& Goebel (1994), to justify the placement of YT- $1101^{\mathrm{T}}$ within a novel species of the genus Cohnella. In the neighbour-joining phylogenetic tree (Fig. 1), YT- $1101^{\mathrm{T}}$ was affiliated to the genus Cohnella, and formed a distinct lineage with respect to closely related species. The topology of the phylogenetic tree constructed by using the maximum-parsimony algorithm was similar to that of the neighbour-joining tree (not shown).

Strain YT- $1101^{\mathrm{T}}$ differed from C. laeviribosi, its closest relative, in terms of the Gram-staining reaction, motility, DNA $\mathrm{G}+\mathrm{C}$ content and temperature and $\mathrm{pH}$ ranges for growth. Strain YT- $1101^{\mathrm{T}}$, but not C. laeviribosi, could be grown in the presence of $2 \% \mathrm{NaCl}$. Fatty acid and polar lipid profiling clearly differentiated $\mathrm{YT}-1101^{\mathrm{T}}$ from the remaining species of Cohnella. In addition, strain YT-1101 ${ }^{\mathrm{T}}$ could be distinguished from members of the genus Cohnella by substrate-utilization patterns (Table 1).

On the basis of the data presented, we propose that strain YT- $1101^{\mathrm{T}}$ represents a novel species of the genus Cohnella, for which the name Cohnella fontinalis sp. nov. is proposed.

\section{Description of Cohnella fontinalis sp. nov.}

Cohnella fontinalis (fon.ti.na'lis. L. fem. adj. fontinalis of or from a fountain, referring to the isolation of the type strain from fresh water from a fountain).

Cells are Gram-type-positive, aerobic, endospore-forming rods, $0.5-0.7 \times 1.5-6.5 \mu \mathrm{m}$. Motile by means of peritrichous flagella. Colonies are irregular, translucent, creamcoloured and usually $1.0-1.5 \mathrm{~mm}$ in diameter within $48 \mathrm{~h}$ 


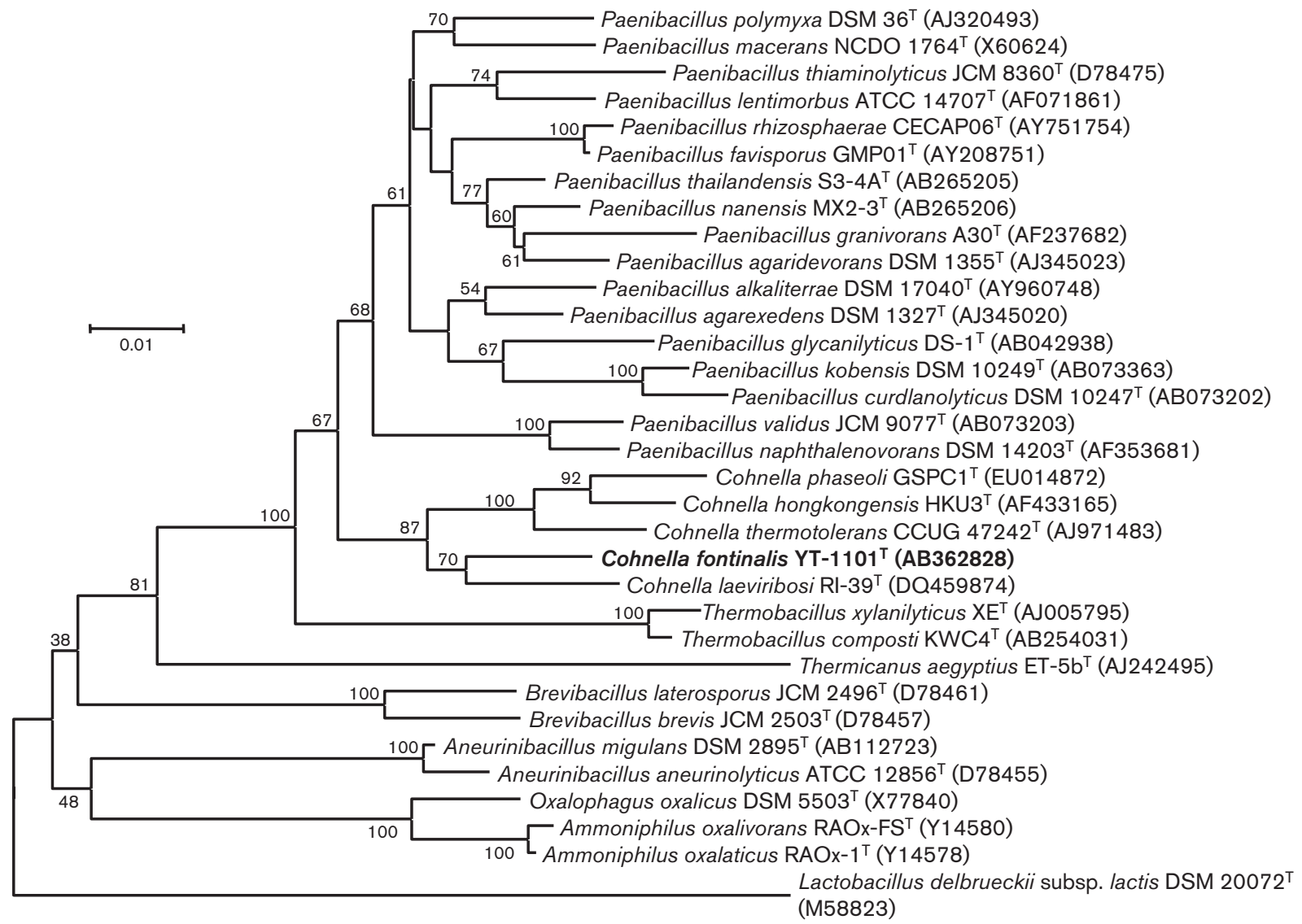

Fig. 1. Neighbour-joining phylogenetic tree based on $16 \mathrm{~S}$ rRNA gene sequences showing the relationship of strain $\mathrm{YT}^{\mathrm{T}}-1101^{\top}$ with representatives from related genera. Bootstrap values (expressed as percentages of 1000 resampled datasets) are shown where $>50 \%$. The sequence of Lactobacillus delbrueckii subsp. lactis DSM $20072^{\top}$ was used as an outgroup. Bar, 0.01 substitutions per nucleotide position.

at $40{ }^{\circ} \mathrm{C}$ on TSA. Growth occurs at $25-55{ }^{\circ} \mathrm{C}$ (optimum $40{ }^{\circ} \mathrm{C}$ ) and $\mathrm{pH}$ 5.5-8.5 (optimum $\mathrm{pH}$ 6.0-7.0). Growth occurs at $\mathrm{NaCl}$ concentrations of up to $2.0 \%(\mathrm{w} / \mathrm{v})$. Oxidase- and catalase-positive. Hydrolysis of xylan and aesculin is positive, while that of DNA, starch, agar, chitin, cellulose, casein, gelatin and tyrosine is negative. Positive for nitrate reduction. Negative for indole production, urease, lecithinase and lipase. $\beta$-Galactosidase is produced, but arginine dihydrolase, lysine decarboxylase, ornithine decarboxylase and tryptophan deaminase are not produced (API 20E). Acetoin and hydrogen sulfide are not produced. The following compounds in the API $20 \mathrm{NE}$ and API $50 \mathrm{CH}$ system are assimilated: D-glucose, L-arabinose, D-mannose, D-mannitol, maltose and potassium gluconate. The following compounds are not utilized as carbon and energy sources: $\mathrm{N}$-acetyl-D-glucosamine, capric acid, adipic acid, malic acid, trisodium citrate, phenylacetic acid, glycerol, erythritol, ribose, xylose, adonitol, methyl $\beta$-D-xylopyranoside, galactose, fructose, sorbose, rhamnose, dulcitol, sorbitol, methyl $\alpha$-D-mannopyranoside, methyl $\alpha$-D-glucopyranoside, amygdalin, arbutin, salicin, cellobiose, lactose, melibiose, sucrose, trehalose, inulin, melezitose, raffinose, glycogen, xylitol, gentiobiose, turanose, D-lyxose, D-tagatose, fucose, arabitol, 2-ketogluconate and 5-ketogluconate. The major isoprenoid quinone is MK-7. The major fatty acids are anteiso- $\mathrm{C}_{15: 0}$, iso- $\mathrm{C}_{16: 0}$ and iso- $\mathrm{C}_{15: 0}$. Predominant polar lipids are diphosphatidylglycerol, phosphatidylglycerol and phosphatidylethanolamine. The genomic DNA $\mathrm{G}+\mathrm{C}$ content of the type strain is $58.6 \mathrm{~mol} \%$.

The type strain, YT $-1101^{\mathrm{T}}\left(=\mathrm{NBRC} 104957^{\mathrm{T}}=\mathrm{DSM}\right.$ $\left.21753^{\mathrm{T}}\right)$, was isolated from fresh water of a fountain in Japan.

\section{Acknowledgements}

We thank Dr Tomoko Aizawa for advice on analysis of polar lipids and helpful discussion and Shoichi Amano for his assistance with microscopic observations. This study was supported by the High-tech Research Center Project of the Ministry of Education, Culture, Sports, Science and Technology, Japan. 


\section{References}

Bartholomew, J. W. \& Mittwer, T. (1952). The Gram stain. Bacteriol Rev 16, 1-29.

Cho, E. A., Lee, J. S., Lee, K. C., Jung, H. C., Pan, J. G. \& Ryun, Y. R. (2007). Cohnella laeviribosi sp. nov., isolated from a volcanic pond. Int J Syst Evol Microbiol 57, 2902-2907.

Felsenstein, J. (1985). Confidence limits on phylogenies: an approach using the bootstrap. Evolution 39, 783-791.

Fitch, W. M. (1971). Toward defining the course of evolution: minimum change for a specific tree topology. Syst Zool 20, 406-416.

García-Fraile, P., Velázquez, E., Mateos, P. F., Martínez-Molina, E. \& Rivas, R. (2008). Cohnella phaseoli sp. nov., isolated from root nodules of Phaseolus coccineus in Spain, and emended description of the genus Cohnella. Int J Syst Evol Microbiol 58, 1855-1859.

Kämpfer, P., Rosselló-Mora, R., Falsen, E., Busse, H.-J. \& Tindall, B. J. (2006). Cohnella thermotolerans gen. nov., sp. nov., and classification of 'Paenibacillus hongkongensis' as Cohnella hongkongensis sp. nov. Int J Syst Evol Microbiol 56, 781-786.

Kimura, M. (1983). The Neutral Theory of Molecular Evolution. Cambridge: Cambridge University Press.

Komagata, K. \& Suzuki, K. (1987). Lipid and cell-wall analysis in bacterial systematics. Methods Microbiol 19, 161-207.

Kumar, S., Tamura, K. \& Nei, M. (2004). MEGA3: integrated software for molecular evolutionary genetics analysis and sequence alignment. Brief Bioinform 5, 150-163.

Mesbah, M. \& Whitman, W. B. (1989). Measurement of deoxyguanosine/thymidine ratios in complex mixtures by high-performance liquid-chromatography for determination of the mole percentage guanine + cytosine of DNA. J Chromatogr 479, 297-306.

Nishijima, M., Araki, M. \& Sano, H. (1997). Identification of isoprenoid quinones by frit-FAB liquid chromatography mass spectrometry for the chemotaxonomy of microorganisms. J Microbiol Methods 28, 113-122.

Saitou, N. \& Nei, M. (1987). The neighbor-joining method: a new method for reconstructing phylogenetic trees. Mol Biol Evol 4, 406425.

Stackebrandt, E. \& Goebel, B. M. (1994). Taxonomic note: a place for DNA-DNA reassociation and 16S rRNA sequence analysis in the present species definition in bacteriology. Int J Syst Bacteriol 44, 846849.

Teng, J. L. L., Woo, P. C. Y., Leung, K. W., Lau, S. K. P., Wong, M. K. M. \& Yuen, K. Y. (2003). Pseudobacteraemia in a patient with neutropenic fever caused by a novel Paenibacillus species: Paenibacillus hongkongensis sp. nov. Mol Pathol 56, 29-35.

Thompson, J. D., Higgins, D. G. \& Gibson, T. J. (1994). CLUSTAL W: improving the sensitivity of progressive multiple sequence alignment through sequence weighting, position-specific gap penalties and weight matrix choice. Nucleic Acids Res 22, 4673-4680.

Tindall, B. J., Sikorski, J., Smibert, R. A. \& Krieg, N. R. (2007). Phenotypic characterization and the principles of comparative systematics. In Methods for General and Molecular Microbiology, 3rd edn, pp. 330-393. Edited by C. A. Reddy, T. J. Beveridge, J. A. Breznak, G. A. Marzluf, T. M. Schmidt \& L. R. Snyder. Washington, DC: American Society for Microbiology.

Toda, T. (1928). Flagellar staining. Nihon Ijishinpo 283, 113 (in Japanese).

Ueda, K., Tagami, Y., Kamihara, Y., Shiratori, H., Takano, H. \& Beppu, T. (2008). Isolation of bacteria whose growth is dependent on high levels of $\mathrm{CO}_{2}$ and implications of their potential diversity. Appl Environ Microbiol 74, 4535-4538.

Wang, X., Hoefel, D., Saint, C. P., Monis, P. T. \& Jin, B. (2007). The isolation and microbial community analysis of hydrogen producing bacteria from activated sludge. J Appl Microbiol 103, 1415-1423. 